\title{
Evolving treatment approaches for the management of metastatic castration-resistant prostate cancer - role of radium-223
}

REVIEW

This article was published in the following Dove Press journal:

Therapeutics and Clinical Risk Management

23 May 2014

Number of times this article has been viewed

\author{
Deborah Mukherji' \\ Imane El Dika' \\ Sally Temraz' \\ Mohammed Haidar ${ }^{2}$ \\ Ali Shamseddine' \\ 'Department of Hematology/ \\ Oncology, ${ }^{2}$ Department of Nuclear \\ Medicine, American University \\ of Beirut Medical Center, Beirut, \\ Lebanon
}

\begin{abstract}
Radium-223 is a first-in-class alpha particle-emitting radiopharmaceutical approved for the treatment of bone metastatic castration-resistant prostate cancer. Radium-223 is administered intravenously with no requirement for complex shielding and specifically targets areas of bone metastasis. In a randomized placebo-controlled Phase III study, treatment with radium-223 was shown to improve overall survival, time to skeletal-related events, and health-related quality of life. Apart from radium-223, the cytotoxic chemotherapy agents docetaxel and cabazitaxel, androgen biosynthesis inhibitor abiraterone acetate, novel anti-androgen enzalutamide, and immunotherapy sipuleucel-T have also been shown to improve survival of men with advanced prostate cancer in Phase III trials. This review will outline current treatment approaches for advanced prostate cancer with a focus on the role of radium-223 in changing treatment paradigms.
\end{abstract}

Keywords: Alpharadin, alpha-emitting radionuclide, bone metastasis

\section{Introduction}

Radium-223 dichloride (radium-223, Xofigo [previously known as Alpharadin; Bayer AG, Leverkusen, Germany]) is a novel alpha-emitting radionuclide recently approved for the treatment of castration-resistant prostate cancer (CRPC) metastatic to bone. Radium-223 administered intravenously forms a complex with hydroxyapatite, selectively targeting areas of increased bone turnover associated with bone metastasis. ${ }^{1}$ Beta-emitting radiopharmaceuticals such as strontium-89 and samarium-153 have been used in the past for palliation of bone pain associated with diffuse metastatic disease; however, duration of response is relatively short with no evidence of an impact on survival. ${ }^{2,3}$

In a randomized Phase III study (ALSYMPCA [ALphradin in SYMptomatic Prostate CAncer Patients]), treatment with radium-223 significantly prolonged survival of patients with bone metastatic CRPC compared to placebo, resulting in approval for use in this setting in the United States in May 2013. ${ }^{4}$ This review will outline current treatment approaches for advanced prostate cancer with a focus on the role of radium223 in changing treatment paradigms.

Data for this review were compiled using MEDLINE/PubMed, American Society of Clinical Oncology (ASCO), and European Society of Medical Oncology (ESMO) abstracts published before February 2014. The search terms included "castrate resistant prostate cancer", "radium-223", "Alpharadin", “abiraterone”, “enzalutamide”, "cabazitaxel", and "sipuleucel-T". Information regarding ongoing clinical trials was obtained using the United Stated National Institute of Health's online resource clinicaltrials.gov. Only articles published in English were considered.
Correspondence: Deborah Mukher Department of Hematology/Oncology, American University of Beirut Medical Center, PO Box: I I-0236, Riad El Solh, Beirut II 07 202, Lebanon

Tel +961 1350000

Emaildm25@aub.edu.lb 


\section{Existing and emerging treatment options for CRPC}

The treatment of advanced prostate cancer is rapidly evolving; patients are living longer with better quality of life despite a diagnosis of castration-resistant disease. ${ }^{5}$ Apart from radium-223, the cytotoxic chemotherapy agents docetaxel and cabazitaxel, androgen biosynthesis inhibitor abiraterone acetate, novel anti-androgen enzalutamide, and immunotherapy sipuleucel-T have also been shown to improve survival of men with CRPC in randomized Phase III trials (see Table 1) ${ }^{6-10}$ Table 2 summarizes currently available treatment options for asymptomatic CRPC and symptomatic CRPC in the first-, second-, and third-line settings.

\section{Cytotoxic chemotherapy}

Docetaxel chemotherapy became the standard of care for the treatment of CRPC in 2004 following the publication of two randomized trials showing a survival advantage over mitoxantrone. ${ }^{10,11}$ Three artificial treatment spaces then emerged in prostate cancer drug development: pre-docetaxel, docetaxel combinations, and post-docetaxel. Despite promising signals in Phase II studies, attempts to combine docetaxel with novel therapeutics have been unsuccessful to date. Negative results have been announced for large Phase III trials combining docetaxel with the endothelin receptor antagonist atrasentan, ${ }^{12}$ the tyrosine kinase inhibitor dasatinib, ${ }^{13}$ and the antiangiogenic agents bevacizumab,${ }^{14}$ lenalidomide, ${ }^{15}$ and aflibercept. ${ }^{16}$

Drug development in the pre- and post-docetaxel settings has been more successful (Table 1). Cabazitaxel is a novel taxane cytotoxic chemotherapy shown to improve survival in men with CRPC post-docetaxel compared to second-line mitoxantrone. ${ }^{6}$ Treatment with cabazitaxel is associated with significant myelosuppression with relatively high rates of febrile neutropenia reported in the Phase III TROPIC study. Data from expanded-access programs have shown that, with experience and appropriate use of growth factor support, toxicity is manageable with good quality of life outcomes. ${ }^{17}$

\section{Targeting androgen receptor signaling}

The androgen receptor (AR) signaling pathway remains a key driver of disease progression in CRPC. ${ }^{18,19}$ The peripheral conversion of circulating adrenal androgens and de novo intratumoral androgen synthesis are mechanisms leading to continued AR signaling; however, activation of this pathway may also be ligand-independent. ${ }^{20-22}$ Preclinical data suggest that, in addition to direct cytotoxic effects, taxanes such as

Table I Systemic treatment options for advanced prostate cancer showing survival benefit in randomized studies

\begin{tabular}{|c|c|c|c|}
\hline $\begin{array}{l}\text { Drug and mechanism } \\
\text { of action }\end{array}$ & Patient population and intervention & Median survival & Reference \\
\hline \multirow[t]{2}{*}{$\begin{array}{l}\text { Abiraterone, CYPI7- } \\
\text { inhibitor }\end{array}$} & $\begin{array}{l}\mathrm{n}=\mathrm{I}, 196, \text { CRPC progressing after docetaxel. } \\
\text { Abiraterone plus prednisone versus placebo } \\
\text { plus prednisone. }\end{array}$ & $\begin{array}{l}\text { I5.8 versus II } .2 \text { months }(\mathrm{HR} 0.74 \text {, } \\
95 \% \mathrm{Cl} 0.64-0.86, P<0.00 \mathrm{I})\end{array}$ & de Bono et $\mathrm{al}^{7}$ \\
\hline & $\begin{array}{l}\mathrm{n}=\mathrm{I}, 088, \text { CRPC, asymptomatic or minimally } \\
\text { symptomatic, docetaxel naïve. Abiraterone plus } \\
\text { prednisone versus placebo plus prednisone. }\end{array}$ & $\begin{array}{l}35.3 \text { versus } 30.1 \text { months }(\mathrm{HR} 0.75 \text {, } \\
95 \% \mathrm{Cl} 0.6 \mathrm{I}-0.94, P=0.0 \mathrm{I})\end{array}$ & Ryan et $\mathrm{a}^{25}$ \\
\hline \multirow[t]{2}{*}{$\begin{array}{l}\text { Enzalutamide, second } \\
\text { generation antiandrogen }\end{array}$} & $\begin{array}{l}\mathrm{n}=\mathrm{I}, 199, \mathrm{CRPC} \text { progressing after docetaxel. } \\
\text { Enzalutamide versus placebo. }\end{array}$ & $\begin{array}{l}18.4 \text { versus } 13.6 \text { months (HR } 0.63 \text {, } \\
95 \% \mathrm{Cl} 0.53-0.75, P<0.00 \mathrm{I})\end{array}$ & Scher et al ${ }^{8}$ \\
\hline & $\begin{array}{l}\mathrm{n}=I, 7 \mid 7, \text { CRPC, asymptomatic or minimally } \\
\text { symptomatic, docetaxel naïve. Enzalutamide } \\
\text { versus placebo. }\end{array}$ & $\begin{array}{l}\text { Estimated } 32.4 \text { versus } 30.2 \text { months } \\
\text { (HR } 0.70,95 \% \mathrm{Cl} 0.59-0.83, P<0.00 \mathrm{I})\end{array}$ & Beer et $\mathrm{al}^{27}$ \\
\hline $\begin{array}{l}\text { Docetaxel, cytotoxic } \\
\text { chemotherapy }\end{array}$ & $\begin{array}{l}n=1,006, \text { CRPC. Docetaxel plus prednisone } \\
\text { 3-weekly versus docetaxel plus prednisone } \\
\text { weekly versus mitoxantron plus prednisone. }\end{array}$ & $\begin{array}{l}19.2 \text { versus } 16.3 \text { months }(\mathrm{HR} 0.76 \text {, } \\
95 \% \mathrm{Cl} 0.62-0.94, P<0.00 \mathrm{I})\end{array}$ & Tannock et al ${ }^{10}$ \\
\hline $\begin{array}{l}\text { Cabazitaxel, cytotoxic } \\
\text { chemotherapy }\end{array}$ & $\begin{array}{l}\mathrm{n}=755 \text {, CRPC progressing after docetaxel. } \\
\text { Cabazitaxel plus prednisone versus } \\
\text { mitoxantrone plus prednisone. }\end{array}$ & $\begin{array}{l}15.1 \text { versus } 12.7 \text { months }(\mathrm{HR} 0.70 \text {, } \\
95 \% \mathrm{Cl} 0.59-0.83, P<0.00 \mathrm{I})\end{array}$ & de Bono et $\mathrm{al}^{6}$ \\
\hline $\begin{array}{l}\text { Radium-223, alpha-emitting } \\
\text { radio nucleotide }\end{array}$ & $\begin{array}{l}\mathrm{n}=922, \text { CRPC after docetaxel or unfit for } \\
\text { docetaxel. Radium- } 223 \text { versus placebo. }\end{array}$ & $\begin{array}{l}14.9 \text { versus } \mathrm{II} .3 \text { months }(\mathrm{HR} 0.70 \text {, } \\
95 \% \mathrm{Cl} 0.55-0.86, P<0.00 \mathrm{I})\end{array}$ & Parker et $\mathrm{al}^{4}$ \\
\hline Sipuleucel-T, immunotherapy & $\begin{array}{l}n=5 \mid 2, \text { CRPC, docetaxel naïve. Sipuleucel- } T \\
\text { versus placebo. }\end{array}$ & $\begin{array}{l}25.8 \text { versus } 21.7 \text { months }(\mathrm{HR} 0.78 \text {, } \\
95 \% \mathrm{Cl} 0.6 \mathrm{I}-0.98)\end{array}$ & Kantoff et al $^{9}$ \\
\hline
\end{tabular}

Abbreviations: $\mathrm{Cl}$, confidence interval; CRPC, castration-resistant prostate cancer; $\mathrm{HR}$, hazard ratio. 
Table 2 Systemic treatment options for patients with metastatic castration-resistant prostate cancer progressing after LHRH and antiandrogen therapy

\begin{tabular}{|c|c|c|c|}
\hline $\begin{array}{l}\text { Asymptomatic or minimally } \\
\text { symptomatic CRPC }\end{array}$ & $\begin{array}{l}\text { Symptomatic CRPC } \\
\text { first-line }\end{array}$ & $\begin{array}{l}\text { CRPC second-line } \\
\text { (post-docetaxel) }\end{array}$ & $\begin{array}{l}\text { Third-line and further } \\
\text { treatments }\end{array}$ \\
\hline Abiraterone* & Docetaxel* & Cabazitaxel* & $\begin{array}{l}\text { Consider clinical trial } \\
\text { participation, eg, cabozantinib }\end{array}$ \\
\hline Sipuleucel-T* & Abiraterone* & Abiraterone* & Cabazitaxel \\
\hline Enzalutamide* & Enzalutamide* & Enzalutamide* & Enzalutamide \\
\hline Docetaxel* & $\begin{array}{l}\text { Radium-223, in patients } \\
\text { not fit for docetaxel* }\end{array}$ & Radium-223* & Abiraterone \\
\hline $\begin{array}{l}\text { Treatment options with no } \\
\text { proven survival benefit } \\
\text { - Estrogens } \\
\text { - Ketoconazole } \\
\text { - Dexamethasone }\end{array}$ & $\begin{array}{l}\text { Consider clinical trial } \\
\text { participation }\end{array}$ & $\begin{array}{l}\text { Consider clinical } \\
\text { trial participation }\end{array}$ & Docetaxel retreatment (Phase II data) \\
\hline Consider clinical trial participation & & $\begin{array}{l}\text { Treatment options wi } \\
\text { - Mitoxantrone } \\
\text { - Estrogens } \\
\text { - Samarium } \\
\text { - Strontium }\end{array}$ & roven survival benefit \\
\hline
\end{tabular}

Note: *Treatments with level I evidence.

Abbreviations: CRPC, castration-resistant prostate cancer; LHRH, luteinizing-hormone-releasing hormone.

docetaxel and cabazitaxel may also act via inhibition of AR nuclear translocation. ${ }^{23}$

Abiraterone acetate (Zytiga; Janssen Biotech Inc, Horsham, PA, USA) is an oral inhibitor of CYP17A1, a key enzyme in the testosterone biosynthesis pathway. The use of single-agent abiraterone leads to a rebound increase in luteinizing hormone, hence the development of abiraterone for use in combination with medical or surgical castration. ${ }^{24}$ The addition of low-dose glucocorticoid resulted in normalization of mineralocorticoid levels and an improvement in blood pressure control in early-phase studies, leading investigators to recommend that abiraterone should be used with prednisone in further clinical trials. Abiraterone 1,000 mg daily plus prednisone has been approved for use in the pre- and post-docetaxel setting for CRPC following two Phase III studies demonstrating superiority over prednisone plus placebo (Table 1). ${ }^{7,25}$

Enzalutamide (Xtandi; Astellas Pharma Inc., Tokyo, Japan) is an oral androgen receptor antagonist that binds to the androgen receptor more avidly than first generation anti-androgens. ${ }^{26}$ The Phase III AFFIRM study, which randomized patients with metastatic CRPC who had progressed after docetaxel chemotherapy to enzalutamide $160 \mathrm{mg}$ daily versus placebo, showed a significant survival benefit associated with enzalutamide treatment. ${ }^{8}$ Enzalutamide has recently been shown to improve both radiographic progression-free survival and overall survival (OS) versus placebo prechemotherapy in CRPC, with approval in this setting anticipated in 2014. ${ }^{27}$ A potential advantage of enzalutamide over androgen biosyn- thesis inhibitors such as abiraterone is the fact that concurrent steroids are not required; however, approximately $30 \%$ of patients in each arm of the AFFIRM study received concurrent corticosteroid treatment. ${ }^{8}$

\section{Immunotherapy}

The approval of sipuleucel-T (Provenge; Dendreon, Seattle, WA, USA) for the treatment of prostate cancer in April 2010 saw the first antigen-specific immunotherapy to be approved for cancer treatment. Preclinical studies demonstrated that dendritic cells loaded with an antigen-cytokine fusion protein consisting of prostatic acid phosphatase (PAP) and granulocyte-macrophage colony-stimulating factor (GM-CSF) induced strong cellular immune responses in vivo to tumors and tissues expressing PAP. ${ }^{28}$ Based on these preclinical observations, sipuleucel-T was developed for clinical use, consisting of autologous dendritic cells loaded with the human PAP-GM-CSF fusion protein.

Sipuleucel-T is individually manufactured for each patient, which involves harvesting peripheral-blood mononuclear cells and their ex vivo incubation with the chimeric protein linking GM-CSF to PAP. Three intravenous infusions are given over a 4-week period. In a Phase III trial involving 512 patients with minimally symptomatic CRPC, median OS was 25.8 months in the group treated with sipuleucel-T compared with 21.7 months in the placebo group (unadjusted hazard ratio [HR] for death in the sipuleucel-T group 0.77; $95 \%$ confidence interval $[\mathrm{CI}] 0.61-0.97, P=0.02) .{ }^{9}$ 


\section{Bone-targeted therapy}

Bone metastases are a major cause of prostate cancer-specific morbidity and mortality. The treatment and prevention of skeletal related events (SREs) in prostate cancer has the potential to impact both symptoms and survival in advanced disease. Bisphosphonates such as zoledronic acid and the novel receptor activation of nuclear factor kappa-B (RANK) ligand inhibitor denosumab (Xgeva; Amgen, Thomas Oaks, CA, USA) are commonly used in combination with other forms of systemic therapy for CRPC.

RANK signaling is a potent stimulus for osteoclast proliferation and bone resorption. Denosumab is a fully humanized monoclonal antibody targeting RANK-ligand that has recently been shown to be superior to zoledronic acid in preventing or delaying SREs in patients with bone metastases from CRPC. ${ }^{29}$ A large double-blind Phase III noninferiority study randomized 1,904 patients to denosumab $120 \mathrm{mg}$ subcutaneously monthly or zoledronic acid $4 \mathrm{mg}$ intravenously monthly. The primary endpoint was time to SRE as defined by pathological fracture, radiotherapy to bone, surgery to bone, or spinal cord compression. Denosumab was shown to be superior to zoledronic acid for prevention of SRE (median time to SRE 20.7 months versus 17.1 months; HR $=0.82 ; P=0.008) .{ }^{29}$ A Phase III placebo-controlled study also demonstrated that denosumab significantly improved bone metastasis-free survival in men with CRPC (29.5 versus 25.2 months; $\mathrm{HR}=0.85$;
95\% CI: $0.73-0.98 ; P=0.028)$; however there was no improvement in OS. ${ }^{30}$

\section{Radium-223: mechanism of action}

Radium-223 is an alpha particle-emitting radionuclide that delivers tumor cell-damaging radiation directly to sites of bone metastasis. Radium forms complexes with the bone mineral hydroxyapatite as a natural calcium mimetic, preferentially targeting areas of increased bone turnover associated with metastatic disease. ${ }^{31}$ Radium-223 is administered intravenously in chloride salt solution, decaying to stable lead-207 in a six-stage process. Four alpha particles are emitted per decay, accounting for approximately $95 \%$ of the total radiation energy emitted. ${ }^{32}$

Alpha particles (composed of two protons and two neutrons) have more than 7,000 times the mass of beta particles, resulting in high linear energy transfer and significantly more biological damage over a very short range (Figure 1). The relatively long range of beta-emitting radiopharmaceuticals may cause significant bone marrow suppression and limit repeated administration. ${ }^{33}$ The track length of the alpha particle is $0.10 \mathrm{~mm}$ (five to ten cell diameters) compared with $0.6 \mathrm{~mm}$ for samarium- 153 and $2.4 \mathrm{~mm}$ for strontium- 89 , limiting damage to normal tissues. ${ }^{1}$ Preclinical studies performed in rats demonstrated a significant bone marrow-sparing advantage with radium-223 compared with strontium-89. ${ }^{34}$

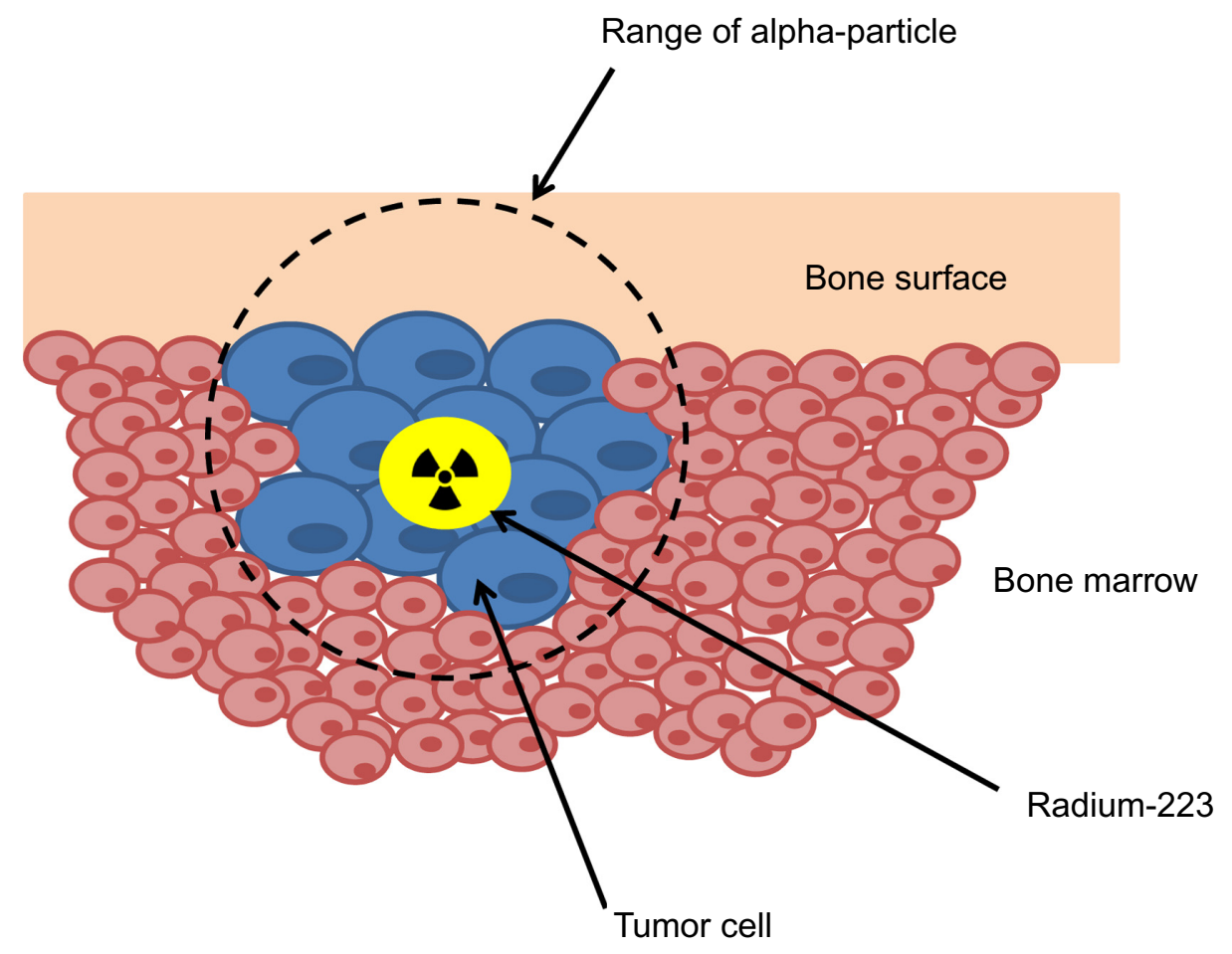

Figure I Mechanism of action of radium-223. 
In an experimental bone metastasis model in nude rats, radium-223 was found to be selectively concentrated in bone compared with soft tissues with a dose-dependent increase in symptom-free survival observed. ${ }^{35}$

Radium-223 is rapidly cleared from the blood following intravenous injection. In a Phase I pharmacokinetic and biodistribution study, $60 \%$ of injected radioactivity was sequestered in bone metastasis within 4 hours and the highest absorbed radiation doses were to the osteogenic cells, red bone marrow, and intestinal wall. Radium-223 is not metabolized by the body and excretion is predominately fecal; renal excretion is less than 5\%. . $^{36,37}$

Raduim-223 is administered using conventional nuclear medicine equipment on an outpatient basis with few radiation protection limitations recommended post-therapy, since the activity administered is considerably lower than the levels administered in standard diagnostic nuclear medicine studies. In patients treated in the Phase I study, dose rates from patients were typically less than $2 \mu \mathrm{Sv} / \mathrm{h} / \mathrm{MBq}$ on contact and averaged $0.02 \mu \mathrm{Sv} \mathrm{h}{ }^{-1} \mathrm{MBq}^{-1}$ at 1 minute immediately following administration. ${ }^{38}$

\section{Radium-223: efficacy and safety}

Early-phase clinical development of radium-223 has been reviewed in detail. ${ }^{39}$ A randomized Phase II study of radium-223 in patients with CRPC and symptomatic bone metastasis showed a significant improvement in serum alkaline phosphatase (ALP) and delayed time to prostate specific antigen progression, and an improved median overall survival at 2 years. ${ }^{40,41}$ The subsequent Phase III ALYSMPCA study randomized 921 patients in a 2:1 ratio to receive six 4-weekly intravenous injections of radium-223 $(50 \mathrm{kBq} / \mathrm{kg})$ or placebo. Eligible patients had progressive symptomatic CRPC with two or more bone metastasis on bone scintigraphy scan and no evidence of visceral disease. Patients randomized within this study had either received or were deemed unfit to receive docetaxel chemotherapy. Recruitment took place from June 2008 to February 2011 and the study was stopped in June 2011 on the recommendation of an independent data monitoring committee after a planned interim analysis showed a significant improvement in overall survival in the patients who received radium-223 compared with placebo.

The two arms of the study were well-balanced in terms of patient characteristics with a median age of 71 years. In both the group of patients treated with radium-223 and those treated with placebo, $57 \%$ had received prior docetaxel chemotherapy. In an updated analysis, median overall survival was 14.9 months in the radium-223 group and 11.3 months in the placebo group
(HR 0.70; 95\% CI 0.58-0.83; $P<0.001$ ). The survival benefit associated with radium-223 was consistent across all subgroups irrespective of factors including baseline ALP level, bisphosphonate use, or prior docetaxel treatment. ${ }^{4}$

Key secondary endpoints of the study included time to first SRE, time to ALP progression, and time to prostate-specific antigen progression. Time to first SRE was significantly prolonged in the group receiving radium-223 (15.6 months versus 9.8 months; HR 0.66 ; 95\% CI $0.52-0.82 ; P<0.001$ ). In particular, radium-223 was effective in significantly reducing the rate of spinal cord compression $(3 \%$ versus $6 \%$ ), pathological fracture (4\% versus $7 \%$ ), and need for external beam radiation therapy ( $23 \%$ versus $27 \%$ ) compared to placebo. ${ }^{42}$

Radium-223 was generally well tolerated with fewer adverse events occurring in patients treated with radium-223 compared with placebo (all adverse events 93\% versus 96\%; grade 3 or 4 adverse events $56 \%$ versus $62 \%$ ). The investigators considered there to be no clinically meaningful differences in the frequency of hematological adverse events between the two groups; however, it should be noted that $6 \%$ of patients treated with radium-223 developed grade 3 or 4 thrombocytopenia compared with $2 \%$ of patients in the placebo group. Only one grade 5 hematologic adverse event was considered possibly related to radium-233 treatment; a patient passed away after developing thrombocytopenia, pneumonia, and hypoxia. Radium-223 was not associated with significant myelosuppression; grade 3 or 4 neutropenia occurred in 3\% of patients treated with radium-223 compared with $1 \%$ of patients in the placebo group. Recently reported follow-up data at 1.5 years showed no increased incidence of second primary cancers, aplastic anemia, or myelodysplasia associated with radium-223 therapy in this cohort. ${ }^{43}$ Of the nonhematologic adverse events potentially related to radium-223, diarrhea was more commonly observed in the experimental group; however, this was generally low-grade and manageable ( $25 \%$ in patients treated with radium-223 compared to $15 \%$ in the placebo group). ${ }^{4}$

\section{Implications for enhanced patient care, improved quality of life}

Data from the ALSYMPCA study suggest that, in addition to prolonging survival, treatment with radium-223 is also associated with an improvement in pain and health-related quality of life. Fewer patients in the radium-223 group required opiate medication for pain relief (36\% versus 50\%) and fewer patients reported pain as an adverse event (50\% versus $62 \%$ ). In the subgroup of patients not requiring opiates at baseline, median time to opiate use was significantly prolonged in the 
Table 3 Radium-223 clinical trials

\begin{tabular}{|c|c|c|c|c|}
\hline $\begin{array}{l}\text { ClinicalTrials.gov } \\
\text { identifier }\end{array}$ & Status & Study & Phase & Design \\
\hline NCT0I934790 & Recruiting & $\begin{array}{l}\text { Re-treatment Safety of Radium-223 Dichloride in Castration-resistant } \\
\text { Prostate Cancer With Bone Metastases }\end{array}$ & $\mathrm{I}, \mathrm{II}$ & Open-label safety \\
\hline NCT00667I99 & Completed & $\begin{array}{l}\text { Study of Radium-223 for the Palliation of Painful Bone Metastases in } \\
\text { (HRPC) Patients }\end{array}$ & II & $\begin{array}{l}\text { Double-blind safety/ } \\
\text { efficacy }\end{array}$ \\
\hline NCT0I798I08 & Completed & $\begin{array}{l}\text { Dose Escalation Study of Radium-223 Dichloride in Patients With } \\
\text { Advanced Skeletal Metastases }\end{array}$ & $\mathrm{I}, \mathrm{II}$ & Open-label safety \\
\hline NCT0069975I & Ongoing & $\begin{array}{l}\text { A Phase III Study of Radium-223 Dichloride in Patients With Symptomatic } \\
\text { Hormone Refractory Prostate Cancer With Skeletal Metastases } \\
\text { (ALSYMPCA) }\end{array}$ & III & Double-blind randomized \\
\hline NCTOII 06352 & Recruiting & $\begin{array}{l}\text { A Study of Alpharadin }{ }^{\circledast} \text { With Docetaxel in Patients With Bone Metastasis } \\
\text { From Castration-Resistant Prostate Cancer (CRPC) }\end{array}$ & $\mathrm{I}, \mathrm{II}$ & Open-label safety/efficacy \\
\hline NCT02043678 & Not open & $\begin{array}{l}\text { Radium-223 Dichloride and Abiraterone Acetate Compared to Placebo } \\
\text { and Abiraterone Acetate for Men With Cancer of the Prostate When } \\
\text { Medical or Surgical Castration Does Not Work and When the Cancer } \\
\text { Has Spread to the Bone, Has Not Been Treated With Chemotherapy } \\
\text { and is Causing no or Only Mild Symptoms }\end{array}$ & III & Double-blind randomized \\
\hline NCT0I070485 & Not applicable & $\begin{array}{l}\text { A Study of Alpharadin }{ }^{\circledR} \text { in Breast Cancer Patients With Bone Dominant } \\
\text { Disease no Longer Considered Suitable for Hormone Therapy }\end{array}$ & $\mathrm{I}, \mathrm{II}$ & Open-label safety/efficacy \\
\hline NCT02023697 & Not open & $\begin{array}{l}\text { Standard Dose Versus High Dose and Versus Extended Standard Dose } \\
\text { Radium-223 Dichloride in Castration-resistant Prostate Cancer Metastatic } \\
\text { to the Bone }\end{array}$ & II & Open-label safety/efficacy \\
\hline NCT02034552 & Recruiting & $\begin{array}{l}\text { A Randomized Open-label Phase lla Study Evaluating the Efficacy and Safety } \\
\text { of Radium-223 Dichloride in Combination With Abiraterone Acetate or } \\
\text { Enzalutamide in Subjects With CRPC Who Have Bone Metastases }\end{array}$ & II & Open-label safety/efficacy \\
\hline NCT0I6I8370 & Recruiting & $\begin{array}{l}\text { Radium(223) Dichloride (Alpharadin) in Castration-Resistant (Hormone- } \\
\text { Refractory) Prostate Cancer Patients With Bone Metastases }\end{array}$ & III & $\begin{array}{l}\text { Prospective open-label } \\
\text { safety }\end{array}$ \\
\hline NCT00748046 & Completed & $\begin{array}{l}\text { Alpharadin }{ }^{\mathrm{TM}} \text { Safety and Dosimetry With HRPC That Has Metastasized } \\
\text { to the Skeleton }\end{array}$ & 1 & $\begin{array}{l}\text { Pharmacokinetics/ } \\
\text { dynamics }\end{array}$ \\
\hline NCT00459654 & Completed & $\begin{array}{l}\text { A Placebo-controlled Phase II Study of Bone-targeted Radium-223 in } \\
\text { Symptomatic Hormone-refractory Prostate Cancer }\end{array}$ & II & Double-blind efficacy \\
\hline NCT00337I55 & Completed & $\begin{array}{l}\text { A Dose Finding Study of Radium-223 for Prostate Cancer Patients With } \\
\text { Bone Metastases }\end{array}$ & II & Double-blind efficacy \\
\hline NCT0I565746 & Ongoing & $\begin{array}{l}\text { Safety, Biodistribution, Radiation Dosimetry and Pharmacokinetics Study } \\
\text { of BAY88-8223 in Japanese Patients }\end{array}$ & 1 & Open-label safety \\
\hline NCT0I833520 & Recruiting & $\begin{array}{l}\text { Phase I Dose Escalation of Monthly Intravenous Ra-223 Dichloride in } \\
\text { Osteosarcoma }\end{array}$ & $\mathrm{I}, \mathrm{II}$ & Open-label safety/efficacy \\
\hline NCT0I929655 & Recruiting & Japanese BAY88-8223 Monotherapy Phase II Study & II & Open-label safety/efficacy \\
\hline
\end{tabular}

radium-223 group compared with placebo (HR 0.62; 96\% CI 0.46-0.85). Treatment with radium-223 significantly prolonged median time to external-beam radiation therapy for bone pain (HR 0.67; 95\% CI 0.53-0.85). ${ }^{44}$

A significantly higher percentage of patients who received radium-223 compared to placebo had a meaningful improvement in quality of life as measured by the FACT-P (functional assessment of cancer therapy - prostate) questionnaire (defined as an increase $\geq 10$ points) during study drug administration $(25 \%$ versus $16 \% ; P=0.02){ }^{4}$

\section{Conclusion, place in therapy}

Radium-223 is a first-in-class alpha particle-emitting radiopharmaceutical shown to prolong overall survival and improve health-related quality of life in bone metastatic CRPC. In the randomized Phase III ALSYMPCA study, radium-223 was evaluated in a cohort of patients who had progressed following docetaxel chemotherapy or who were considered unfit for docetaxel treatment. In this study, 57\% of patients had received prior docetaxel chemotherapy, and it should be noted that the mechanism of action of radium-223 with specific targeting of bone metastatic disease does not preclude its use when any other systemic treatment has failed. ${ }^{45}$ The key question that will determine the place of radium-223 in the sequencing of therapy for CRPC will be the safety of combining this treatment with other survivalprolonging drugs such as abiraterone, enzalutamide, and cabazitaxel. Despite the fact that clinically significant 
myelosuppression was not observed in the patients treated in the ALSYMPCA study, heavily pretreated patients with poor bone marrow reserve may be at risk of significant toxicity associated with radium-223 as a single agent or in combination with other systemic therapies. Several combination studies are ongoing in prostate cancer and other tumor types (Table 3); however, this strategy is not currently recommended outside clinical trials. Another question is the use of radium-223 in patients with both bone and visceral metastasis; if the combination of radium-223 with other systemic therapies proves to be safe and effective, this may become a future standard of care.

At present, radium-223 can be considered for all patients with symptomatic bone-only metastatic disease,${ }^{46}$ particularly those with poor performance status who are unfit for cytotoxic chemotherapy.

\section{Disclosure}

Dr Mukherji reports travel support and honoraria from Janssen and Sanofi, and Dr Shamseddine reports honoraria from Sanofi. Other authors have no conflicts of interest to report.

\section{References}

1. Bruland ØS, Nilsson S, Fisher DR, Larsen RH. High-linear energy transfer irradiation targeted to skeletal metastases by the alpha-emitter 223Ra: adjuvant or alternative to conventional modalities? Clin Cancer Res. 2006;12(20 Pt 2):6250s-6257s.

2. Finlay IG, Mason MD, Shelley M. Radioisotopes for the palliation of metastatic bone cancer: a systematic review. Lancet Oncol. 2005;6(6): 392-400.

3. James ND, Pirrie S, Barton D, et al. Clinical outcomes in patients with castrate-refractory prostate cancer (CRPC) metastatic to bone randomized in the factorial TRAPEZE trial to docetaxel (D) with strontium-89 (Sr89), zoledronic acid (ZA), neither, or both (ISRCTN 12808747). J Clin Oncol. 2013;31(Suppl 18): LBA5000.

4. Parker C, Nilsson S, Heinrich D, et al. Alpha emitter radium-223 and survival in metastatic prostate cancer. N Engl J Med. 2013;369(3): 213-223

5. Omlin A, Pezaro C, Mukherji D, et al. Improved survival in a cohort of trial participants with metastatic castration-resistant prostate cancer demonstrates the need for updated prognostic nomograms. Eur Urol. 2013;64:300-306.

6. de Bono JS, Oudard S, Ozguroglu M, et al. Prednisone plus cabazitaxel or mitoxantrone for metastatic castration-resistant prostate cancer progressing after docetaxel treatment: a randomised open-label trial. Lancet. 2010;376(9747):1147-1154.

7. de Bono JS, Logothetis CJ, Molina A, et al. Abiraterone and increased survival in metastatic prostate cancer. $N$ Engl J Med. 2011;364(21): 1995-2005.

8. Scher HI, Fizazi K, Saad F, et al. Increased Survival with Enzalutamide in Prostate Cancer after Chemotherapy. N Engl J Med. 2012;367(13): 1187-1197.

9. Kantoff PW, Higano CS, Shore ND, et al. Sipuleucel-T immunotherapy for castration-resistant prostate cancer. $N$ Engl J Med. 2010;363(5): 411-422.

10. Tannock IF, de Wit R, Berry WR, et al. Docetaxel plus prednisone or mitoxantrone plus prednisone for advanced prostate cancer. $N$ Engl $J$ Med. 2004;351(15):1502-1512.
11. Petrylak DP, Tangen CM, Hussain MH, et al. Docetaxel and estramustine compared with mitoxantrone and prednisone for advanced refractory prostate cancer. $N$ Engl J Med. 2004;351(15):1513-1520.

12. Quinn DI, Tangen CM, Hussain M, et al. SWOG S0421: Phase III study of docetaxel (D) and atrasentan (A) versus docetaxel and placebo (P) for men with advanced castrate resistant prostate cancer (CRPC). J Clin Oncol. 30, 2012 (Suppl; abstr 4511). 2012.

13. Araujo JC, Trudel GC, Saad F, et al. Overall survival (OS) and safety of dasatinib/docetaxel versus docetaxel in patients with metastatic castrationresistant prostate cancer (mCRPC): Results from the randomized phase III READY trial. J Clin Oncol. 2013 (Suppl 6; abstr LBA8). 2013.

14. Kelly WK, Halabi S, Carducci M, et al. Randomized, double-blind, placebo-controlled phase III trial comparing docetaxel and prednisone with or without bevacizumab in men with metastatic castration-resistant prostate cancer: CALGB 90401. J Clin Oncol. 2012;30(13):1534-1540.

15. Petrylak DP, Fizazi K, Sternberg C, et al. A Phase 3 Study to Evaluate the Efficacy and Safety of Docetaxel and Prednisone (DP) With or Without Lenalidomide (LEN) in Patients with Castrate-Resistant Prostate Cancer (CRPC): The MAINSAIL Trial. esMO Conference 2012 LBA24. 2012.

16. Tannock I, Fizazi K, Ivanov S, et al. Aflibercept versus placebo in combination with docetaxel/prednisone for first-line treatment of men with metastatic castration-resistant prostate cancer (mCRPC): Results from the multinational phase III trial (VENICE). J Clin Oncol. 31, 2013 (Suppl 6; abstr 13). 2013.

17. Bahl A MS, Malik S, Birtle A, et al. Cabazitaxel for metastatic castrationresistant prostate cancer (mCRPC): Interim safety and quality-of-life (QOL) data from the UK early access program (NCT01254279). J Clin Oncol. 2012;30(Suppl 5; abstr 44).

18. Attard G, Cooper CS, de Bono JS. Steroid hormone receptors in prostate cancer: a hard habit to break? Cancer Cell. 2009;16(6):458-462.

19. Nelson PS. Molecular states underlying androgen receptor activation: a framework for therapeutics targeting androgen signaling in prostate cancer. J Clin Oncol. 2012;30(6):644-646.

20. Montgomery RB, Mostaghel EA, Vessella R, et al. Maintenance of intratumoral androgens in metastatic prostate cancer: a mechanism for castration-resistant tumor growth. Cancer Res. 2008;68(11):4447-4454.

21. Titus MA, Schell MJ, Lih FB, Tomer KB, Mohler JL. Testosterone and dihydrotestosterone tissue levels in recurrent prostate cancer. Clin Cancer Res. 2005;11(13):4653-4657.

22. Locke JA, Guns ES, Lubik AA, et al. Androgen levels increase by intratumoral de novo steroidogenesis during progression of castrationresistant prostate cancer. Cancer Res. 2008;68(15):6407-6415.

23. Darshan MS, Loftus MS, Thadani-Mulero M, et al. Taxane-induced blockade to nuclear accumulation of the androgen receptor predicts clinical responses in metastatic prostate cancer. Cancer Res. 2011;71(18): 6019-6029.

24. O'Donnell A, Judson I, Dowsett M, et al. Hormonal impact of the 17alpha-hydroxylase/C(17,20)-lyase inhibitor abiraterone acetate (CB7630) in patients with prostate cancer. Br J Cancer. 2004;90(12): 2317-2325.

25. Ryan CJ, Smith MR, de Bono JS, et al. Abiraterone in Metastatic Prostate Cancer without Previous Chemotherapy. $N$ Engl $J$ Med. 2013;368:138-148.

26. Tran C, Ouk S, Clegg NJ, et al. Development of a second-generation antiandrogen for treatment of advanced prostate cancer. Science. 2009;324(5928):787-790.

27. Beer TMAA, Sternberg CN, Higano CS, et al. Enzalutamide in men with chemotherapy-naive metastatic prostate cancer (mCRPC): Results of phase III PREVAIL study. J Clin Oncol. 2014;32(Suppl 4 LBA1).

28. Small EJ, Fratesi P, Reese DM, et al. Immunotherapy of hormonerefractory prostate cancer with antigen-loaded dendritic cells. J Clin Oncol. 2000;18(23):3894-3903.

29. Fizazi K, Carducci M, Smith M, et al. Denosumab versus zoledronic acid for treatment of bone metastases in men with castrationresistant prostate cancer: a randomised, double-blind study. Lancet. 2011;377(9768):813-822. 
30. Smith MR, Saad F, Coleman R, et al. Denosumab and bone-metastasisfree survival in men with castration-resistant prostate cancer: results of a phase 3, randomised, placebo-controlled trial. Lancet. 2012;379(9810):39-46.

31. Nilsson S, Larsen RH, Fossa SD, et al. First clinical experience with alpha-emitting radium-223 in the treatment of skeletal metastases. Clin Cancer Res. 2005;11(12):4451-4459.

32. McDevitt MR, Sgouros G, Finn RD, et al. Radioimmunotherapy with alpha-emitting nuclides. Eur J Nucl Med. 1998;25(9):1341-1351.

33. Sartor O, Reid RH, Bushnell DL, Quick DP, Ell PJ. Safety and efficacy of repeat administration of samarium Sm-153 lexidronam to patients with metastatic bone pain. Cancer. 2007;109(3):637-643.

34. Henriksen G, Fisher DR, Roeske JC, Bruland ØS, Larsen RH. Targeting of osseous sites with alpha-emitting 223Ra: comparison with the betaemitter 89Sr in mice. J Nucl Med. 2003;44(2):252-259.

35. Henriksen G, Breistøl K, Bruland ØS, Fodstad Ø, Larsen RH. Significant antitumor effect from bone-seeking, alpha-particle-emitting (223)Ra demonstrated in an experimental skeletal metastases model. Cancer Res. 2002;62(11):3120-3125.

36. Hindorf C, Chittenden S, Aksnes AK, Parker C, Flux GD. Quantitative imaging of 223Ra-chloride (Alpharadin) for targeted alpha-emitting radionuclide therapy of bone metastases. Nucl Med Commun. 2012;33(7):726-732.

37. Hafeez S, Parker C. Radium-223 for the treatment of prostate cancer. Expert Opin Investig Drugs. 2013;22(3):379-387.

38. Dauer LT, Williamson MJ, Humm J, et al. Radiation Safety Considerations for the Use of $223 \mathrm{RaCl} 2 \mathrm{DE}$ in Men with Castration-resistant Prostate Cancer. Health Phys. 2014;106(4):494-504.

39. Harrison MR, Wong TZ, Armstrong AJ, George DJ. Radium-223 chloride: a potential new treatment for castration-resistant prostate cancer patients with metastatic bone disease. Cancer Manag Res. 2013;5:1-14.
40. Nilsson S, Franzen L, Parker C, et al. Bone-targeted radium-223 in symptomatic, hormone-refractory prostate cancer: a randomised, multicentre, placebo-controlled phase II study. Lancet Oncol. 2007;8(7): 587-594.

41. Nilsson S, Franzen L, Parker C, et al. Two-year survival follow-up of the randomized, double-blind, placebo-controlled phase II study of radium-223 chloride in patients with castration-resistant prostate cancer and bone metastases. Clin Genitourin Cancer. 2013;11(1):20-26.

42. Parker CNS, Heinrich D, O'Sullivan JM, et al. Updated analysis of the phase III, double-blind, randomized, multinational study of radium-223 chloride in castration-resistant prostate cancer (CRPC) patients with bone metastases (ALSYMPCA). J Clin Oncol. 2012; 30(Suppl):LBA4512.

43. Nilsson SVN, Sartor AO, Bottomley D, et al. 1.5-year post-treatment follow-up of radium-223 dichloride ( $\mathrm{Ra}-223)$ in patients with castrationresistant prostate cancer (CRPC) and bone metastases from the phase 3 ALSYMPCA study. J Clin Oncol. 2014;32(Suppl 4; abstr 9).

44. Nilsson SSA, Bruland OS, Fang F, Aksnes AK, Cisco P, Parker C. Pain analyses from the phase III ransomized ALSYMPCA study with radium-223 dichloride (radium-223) in castration-resistant prostate cancer (CRPC) patients with bone metastasis. J Clin Oncol. 2013;31(Suppl 15).

45. Wissing MD, van Leeuwen FW, van der Pluijm G, Gelderblom H. Radium-223 chloride: Extending life in prostate cancer patients by treating bone metastases. Clin Cancer Res. 2013;19(21): 5822-5827.

46. Mohler JL, Kantoff PW, Armstrong AJ, et al. Prostate cancer, version 1.2014. J Natl Compr Canc Netw. 2013;11(12):1471-1479.
Therapeutics and Clinical Risk Management

\section{Publish your work in this journal}

Therapeutics and Clinical Risk Management is an international, peerreviewed journal of clinical therapeutics and risk management, focusing on concise rapid reporting of clinical studies in all therapeutic areas outcomes, safety, and programs for the effective, safe, and sustained use of medicines. This journal is indexed on PubMed Central, CAS,

\section{Dovepress}

EMBase, Scopus and the Elsevier Bibliographic databases. The manuscript management system is completely online and includes a very quick and fair peer-review system, which is all easy to use. Visit http://www.dovepress.com/testimonials.php to read real quotes from published authors. 